\title{
The ectoparasite mite Varroa destructor Anderson and Trueman in southeastern Brazil apiaries: effects of the hygienic behavior of Africanized honey bees on infestation rates
}

[O ácaro ectoparasita Varroa destructor Anderson e Trueman em apiários do sudeste brasileiro: efeito do comportamento higiênico de abelhas africanizadas nas taxas de infestação]

\author{
F.A. Pinto $^{1}$, A. Puker ${ }^{1}$, L.M.R.C. Barreto ${ }^{2}$, D. Message $^{3}$ \\ ${ }^{1}$ Aluno de Pós-Graduação - Universidade Federal de Viçosa - Viçosa, MG \\ ${ }^{2}$ Universidade de Taubaté - Taubaté, SP \\ ${ }^{3}$ Universidade Federal de Viçosa - Viçosa, MG
}

\begin{abstract}
In Brazil, the ectoparasitic mite of bees Varroa destructor Anderson and Trueman (Acari: Varroidae) remains at low levels of infestation causing no major damage. However, with the introduction and possible dominance of a new haplotype $(K)$ of the mite, usually found in areas with high infestation rates (IR), it is necessary to monitor and select beehives that are resistant to the pest in order to avoid future problems. Several factors are listed as potentially being responsible for the dynamics of mite infestation, among which hygienic behavior (HB) stands out. In this context we sought to evaluate the HB of Africanized honey bees Apis mellifera L. (Hymenoptera: Apidae) compared with the mite IR in apiaries of two municipalities of southeastern Brazil (Taubaté and Viçosa). For the municipality of Taubaté, the average IR was 4.9\% (3.4 to 5.8\%), while the HB averaged $98.6 \%$ (96 to 100\%). In Viçosa, the average mite IR was found to be $10.0 \%$ (5.4 to $21.0 \%$ ) with an average value for $\mathrm{HB}$ of $57.7 \%$ (0 to $79.0 \%$ ). Results from this research show that IR and HB were negatively correlated $(\mathrm{R}=-0.9627, \mathrm{P}<0.01)$, suggesting that hives with higher HB have lower IR.
\end{abstract}

Keywords: Acari, Apidae, bee pathology, pest management, Varroidae

\section{RESUMO}

No Brasil, o ácaro ectoparasita de abelhas Varroa destructor Anderson e Trueman (Acari: Varroidae) se mantém em índices de infestação baixos, não causando grandes prejuízos. Todavia com a introdução e possível predominância de um novo haplótipo $(K)$ do ácaro, geralmente encontrado em regiões com altas taxas de infestação (TI), faz-se necessário o monitoramento e seleção de colônias resistentes à praga, evitando problemas futuros. Vários fatores são relacionados como possíveis responsáveis pela dinâmica de infestação do ácaro, dentre os quais se destaca o comportamento higiênico $(\mathrm{CH})$. Nesse contexto buscamos avaliar o $\mathrm{CH}$ de abelhas africanizadas Apis mellifera L. (Hymenoptera: Apidae) correlacionando com as TI do ácaro em apiários de dois municípios do sudeste brasileiro (Taubaté e Viçosa). Em Taubaté, o valor médio da TI foi de 4,9\% (3,4 a 5,8\%), enquanto que o CH foi em média 98,6\% (96 a 100\%). Já em Viçosa, a TI média do ácaro foi de 10,0\% (5,4 a 21,0\%) com valor médio de $\mathrm{CH}$ de 57,7\% (0 a 77,0\%). Resultados dessa pesquisa demonstraram que as variáveis TI e CH foram negativamente correlacionadas $(R=-0,9627 ; \mathrm{P}<0,01)$, sugerindo que colônias que possuem CH mais elevado possuem menores TI.

Palavras-chave: Acari, Apidae, manejo de pragas, patologia apícola, Varroidae

\section{INTRODUCTION}

In Brazil, apiculture is increasing in importance due to the increase in consumption of its products along with favorable environmental conditions for apiculture, and professionalization of beekeepers, yielding products of better quality (Perosa et al., 2004). With the increase in demand for hive products, more research is needed to improve productivity and to find potential pathogens that may threaten the beehives or cause losses (Perosa et al., 2004).

Recebido em 1 de março de 2011 
The emergence of several diseases and phenomena, such as Colony Collapse Disorder (CCD) has been the cause many losses to this business (Cox-Foxter et al., 2007). Many factors are mentioned as causing $\mathrm{CCD}$, among which parasitism by the mite Varroa destructor Anderson and Trueman (Anderson and Trueman, 2000) may be included.

Varroa destructor is an ectoparasite of adult bees and post-capped brood. It feeds from its host's hemolynph, which may disrupt development and causes death of the entire hive in high infestation rates (IR) (Rosenkranz et al., 2010). The mite was initially characterized as being a parasite of Apis cerana F. (Hymenoptera: Apidae) in Asia (Rosenkranz et al., 2010). However, after being exposed to Apis mellifera L. (Hymenoptera: Apidae), it rapidly spread to several countries (Bailey and Ball, 1991; Rosenkranz et al., 2010). The dispersion in beehives of A. mellifera has deeply impacted the apiculture business causing high hive mortality rate and the need to use acaricides for mite control (Bailey and Ball, 1991; Rosenkranz et al., 2010).

The intensity of the IR of the mite and the losses caused to the hives changes regionally. In Europe, the mite usually causes significant loss and acaricides are widely used (Lodesani et al., 2008). However, in countries such as Brazil the IR remains at lower levels, eliminating the need to use acaricides (De Jong and Gonçalves, 1998). In Brazilian territory, the mite was first observed during the $70 \mathrm{~s}$ in the apiaries of Ribeirão Preto (São Paulo). In the beginning high IR were reported, but after a few years the parasite - host interaction seemed to have stabilized, as the average IR was around 3\%, not causing significant losses to the beehives (De Jong and Gonçalves, 1998).

One of the possible reasons that explain the resistance of $A$. mellifera to the varroa in Brazil is the use of Africanized honey bees, which possibly have characteristics that favor lower mite IR (De Jong, 1996; Rosenkranz et al., 2010). Several studies have indicated that the mite IR and damage is multifactorial. Biotic and abiotic factors have been shown to be significant in the infestation dynamic of the varroa in the beehives. Among these factors, one may highlight temperature (Moretto, 1997; Pinto et al., 2011a), bee race (Moretto et al., 1991;
Rosenkranz et al., 2010), size of brood comb cells (Message and Gonçalves, 1995; Ellis et al., 2009; Maggi et al., 2010), mite genetic variations (haplotype) (Anderson and Trueman, 2000; Calderón et al., 2010) and hygienic behavior (HB) (Peng et al., 1987; Spivak, 1996; Harbo and Harris, 2009).

In general, $\mathrm{HB}$ is defined as the opening and removal of sick, parasitized or dead broods (Spivak, 1996; Rosenkranz et al., 2010). Colonies with high $\mathrm{HB}$ will tend to dispose of the broods parasitized by the mite, and thus interrupt the mite's development cycle which consequently will stop the IR from increasing. $\mathrm{HB}$ is also highly influenced by climatic conditions (Boecking and Spivak, 1999; Harris, 2008). In this context, we evaluated the levels of HB for the Africanized honey bees in apiaries of two Brazilian municipalities (Taubaté and Viçosa), allowing the observation of the influence of this variable on the IR of the mite $V$. destructor.

\section{MATERIAL AND METHODS}

The samples used for this study were obtained from the apiary of the Universidade de Taubaté (Taubaté, Vale do Paraíba, São Paulo, Brazil) and from the apiary of the Universidade Federal de Viçosa (Viçosa, Zona da Mata, Minas Gerais, Brazil). Five hives with a similar population were selected from each apiary, from which the samples were collected during the spring of 2009 and 2010. This season was selected for sample collection because it is characterized by a high flow of nectar and pollen availability in both municipalities.

In order to evaluate the IR, 150 adult bees were harvested from the brood area and were stored in a vessel with $98^{\circ}$ alcohol (method adapted from De Jong et al., 1982). The solution (bees + alcohol) was then agitated so that the mites would be released from the bees' bodies. Finally, the actual number of bees and mites were counted and recorded.

For the evaluation of the hives' HB, a frame with capped brood comb cells from each hive was selected. With entomological pins, 100 capped broods were carefully pin-killed without overflow of the body fluids. After this procedure the sampled area was labeled and the frame was 
placed back inside the beehive in its original position. Twenty-four hours later, the labeled frames were checked and the number of clean cells were counted and recorded, then the hive HB was calculated (adapted from Newton and Ostasiewski, 1986). Pearson's Correlation was performed between $\mathrm{HB}$ and IR of the mite in adult bees.

\section{RESULTS AND DISCUSSION}

The average value for IR of $V$. destructor in adult bees in apiaries of Taubaté was $4.9 \%$, while the average value for $\mathrm{HB}$ was $98.6 \%$. In Viçosa, the mean IR was $10.0 \%$ and the $\mathrm{HB}$ values ranged from 0 to $79 \%$ (Table 1). The hive that did not present HB had a high IR $(21.0 \%)$ (Table 1). The correlation coefficient between $\mathrm{HB}$ and IR was $\mathrm{R}=-0.963(\mathrm{P}<0.01)$ (Figure 1). IR values for the mite reflect the parasite - host relationship inside the beehive. Resistant bees maintain the mite population at low levels, keeping the IR from reaching values that might cause any loss to the beehives (Rosenkranz et al., 2010; Pinto et al., 2011a).
We believe that an important factor that favored the quick adaptation of the Africanized honey bees in Brazil was the initial prevalence of the haplotype $J$ of the mite, usually found in regions with less damage by varroa (Anderson and Trueman, 2000; Strapazzon et al., 2009; Rosenkranz et al., 2010). Garrido et al. (2003) observed a predominance of the haplotype $K$ in beehives of the municipality of Ribeirão Preto (São Paulo, Brazil). This fact may be a warning for a change in the reproductive potential of the mite, which may cause future problems to Brazilian apiculture. However, Pinto et al. (unpublished data) found IR values for the mite that varied from 0 to $5.5 \%$ in 16 municipalities from Vale do Paraíba and Serra da Mantiqueira (São Paulo, Brazil). These values are similar to those found for Taubaté (3.4 to $5.8 \%$ ). It becomes evident then, that the Africanized honey bees are able to keep hive IR at low levels, as compared to other countries, even with the presence of the haplotype $K$ of the mite in state of São Paulo (Brazil) (Garrido et al., 2003). However, there is the need of further research to verify the current situation of the predominant haplotypes in the region.

Table 1. Mean ( \pm Standard Error) infestation rate (IR) of the mite $V$. destructor and hygienic behavior (HB) of Africanized honey bees (A. mellifera) in apiaries of the municipalities of Taubaté (São Paulo, Brazil) and Viçosa (Minas Gerais, Brazil) (minimum-maximum value)

\begin{tabular}{ccc}
\hline & Taubaté & Viçosa \\
\hline IR $(\%)$ & $4.9 \pm 0.42(3.4-5.8)$ & $10.0 \pm 2.84(5.4-21.0)$ \\
HB $(\%)$ & $98.6 \pm 0.75(96.0-100.0)$ & $57.7 \pm 14.71(0.0-79.0)$ \\
\hline
\end{tabular}

The regional variation of the reproductive potential of $V$. destructor is also one of the factors that may explain the IRs. Garrido et al. (2003) observed differences in mite fertility between Ribeirão Preto (São Paulo, Brazil) and Florianópolis (Santa Catarina, Brazil). These values were confirmed by Strapazzon et al. (2009) who found similar levels of fertility $(71 \%)$ in southern Brazil, with a predominance of the haplotype $K$, which may explain the increase in fertility levels in recent years. However, the increase of reproductive potential does not seem to be enough to increase IRs of $V$. destructor in Brazil. Defense mechanisms, such as hygienic and grooming behavior tend to increase as the number of offspring decreases and the number of mites increases in adults (Junkes et al., 2007).

Contrary to what was observed for Taubaté, we found considerably high values for IR in the municipality of Viçosa. Similar values were found by Bacha Júnior et al. (2009), who evaluated IR values for apiaries located in three municipalities of the same micro-region (Zona da Mata) where Viçosa is located. For one of the sampled municipalities, the IR varied from 4.7 to 20.2\% (Bacha Júnior et al., 2009). These authors warned of a possible influence of the abundance of beehives on the dynamics of mite infestation. Regions with high concentrations of beehives, with superposing apiaries, are more prone to the mite infestation. 
The availability of food can also affect the dynamics of mite infestation in the colony. The flow of nectar and pollen is closely related to the rainy periods ranging from one region to another. For example, Pinto et al. (2011a) observed the highest levels of mite infestation on adult bees in dry seasons. The increase in infestation of adult bees in periods of low feed can be related to lack of brood, which favors the increase of the phoretic period of the mite (Rosenkranz et al., 2011). The extension of the period of parasitism because of phoresis may aggravate the effects on host fitness. Pinto et al. (2011b) observed decreases in the average cell area in $11 \%$ of hypopharyngeal glands of bees infested during the pupae stage. Adding long periods of parasitism in adults can affect the production of royal jelly, development of tasks and consequently the survival of the colony (Rosenkranz et al., 2011, Pinto et al., 2011b). However, most tropical/subtropical regions like Brazil have food available almost all year to the colonies (Barreto et al., 2006), which favors the mites in the reproductive phase and during phoresis.

Several studies on IR of $V$. destructor and its reproductive potential have shown that its infestation dynamic is conditioned to several factors. Among them one may highlight $\mathrm{HB}$ as one of the most important (Rosenkranz et al., 2010). Aimed at finding non-chemical methods to control varroa in regions with high levels of infestation, new lines of highly hygienic bees have been tested successfully. Ibrahim and Spivak (2006) analyzing highly tolerant colonies called SMR (Suppression of Mite Reproduction) found high levels of $\mathrm{HB}$ and mite infertility compared with common hygienic colonies. Bees with high $\mathrm{HB}$ are able to remove broods parasitized with the varroa, interrupting the mite's development cycle (Spivak, 1996). This might be one of the reasons for the resistance of the Africanized honey bees to the mite $V$. destructor in Brazil (Spivak, 1996; CôrreaMarques, 1998). Africanized honey bees became adapted to Brazilian climatic conditions, spreading out to almost the entire country, except for southern Brazil due to the temperate climate (Moretto et al., 1991). However, because of the high genetic variability, the high $\mathrm{HB}$ might not be a characteristic that is found in all hives of $A$. mellifera in Brazil. Within the same apiary one will find large variability in $\mathrm{HB}$ as shown by the results presented for Viçosa (0 to 79\%). The beehives evaluated in Taubaté presented the highest levels of $\mathrm{HB}$; these values are considered very homogeneous as compared to those from Viçosa. This fact may be explained by the management practices applied to that apiary such as periodical queen replacement for those that were highly selected genetically to perform a high HB level.

\section{CONCLUSIONS}

HB appears to influence the IR of varroa in the sampled hives. In the apiary of Taubaté, where the HB levels were as high as 96 to $100 \%$, the IR varied from 3.4 to $5.8 \%$. In Viçosa, both HB and mite IR presented high variability. Hives from the apiary of Viçosa, however, did not have queens that were genetically selected; this fact may explain the high variability, along with the abiotic factors that might also have played an important role to the levels of $\mathrm{HB}$ for that region. Besides the fact that the beehives own the ability to develop HB through genetic background, some sort of stimulus is still necessary for the expression of it. For this case, a small IR that would evolve to high $\mathrm{HB}$ for non-selected bees will launch high HB in beehives with genetically selected bees. The periodical substitution of the queens for those with high $\mathrm{HB}$ along with other desirable characteristics is recommended. This practice will yield in better productivity and can also be considered a preventative step against the need for acaricide applications that may contaminate hive products.

\section{ACKNOWLEDGMENTS}

FAP and AP thank "Coordenação de Aperfeiçoamento Pessoal de Nível Superior" (CAPES, Brazil) for the scholarship granted and the Graduate Program in Entomology of the Federal University of Viçosa. We also thank to the anonymous reviewers for their corrections and suggestions in earlier versions of this manuscript. 


\section{REFERENCES}

ANDERSON, D.L.; TRUEMAN, J.W.H. Varroa jacobsoni (Acari: Varroidae) is more than one species. Exp. Appl. Acarol., v.24, p.165-189, 2000

BACHA JÚNIOR, G.L.; FELIPE-SILVA, A.S.; PEREIRA, P.L.L. Taxa de infestação por ácaro Varroa destructor em apiários sob georreferenciamento. Arq. Bras. Med. Vet. Zootec., v.61, p.1471-1473, 2009.

BAILEY, L.; BALL, B.V. Honey bee pathology, 2nd edition. Academic Press, London, UK, 193 p., 1991.

BARRETO, L.M.R.C.; FUNARI, S.R.C.; ORSI, R.O.; DIB, A.P.S. Produção de pólen no Brasil. Cabral Press, Taubaté, Brasil, 100 p., 2006.

BOECKING, O.; SPIVAK, M. Behavioral defenses of honey bees against Varroa jacobsoni Oud. Apidologie, v.30, p.141-158, 1999.

CALDERÓN, R.A.; VAN VEEN, J.W.; SOMMEIJER, M.J.; SANCHEZ, L.A. Reproductive biology of Varroa destructor in Africanized honey bees. Exp. Appl. Acarol., v.50, p.281-297, 2010.

COX-FOXTER, D.L.; CONLAN, S.; HOLMES, E.C. A metagenomic survey of microbes in honey bee Colony Collapse Disorder. Science, v.318, p. 283-287, 2007.

DE JONG, D. Africanized honey bees in Brazil, forty years of adaptation and success. Bee World, v.77, p.67-70, 1996.

DE JONG, D.; GONÇALVES, L.S. The Africanized bees of Brazil have become tolerant to Varroa. Apiacta, v.33, p.67-70, 1998.

DE JONG, D.; ROMA, D.D.; GONÇALVES, L.S. A comparative analysis of shaking solutions for the detection of Varroa jacobsoni on adult honeybees. Apidologie, v.13, p.297-306, 1982.

ELLIS, A.M.; HAYES, G.W.; ELLIS, J.D. The efficacy of small cell foundation as a varroa mite (Varroa destructor) control. Exp. Appl. Acarol., v.47, p.311-316, 2009.

GARRIDO, C.; ROSENKRANZ, P.; PAXTON, R.J.; GONÇALVES, L.S. Temporal changes in Varroa destructor fertility and haplotype in Brazil. Apidologie, v.34, p.535-541, 2003.
HARBO, J.R.; HARRIS, J.W. Responses to varroa by honey bees with different levels of varroa sensitive hygiene. J. Apic. Res., v.48, p.156-161, 2009.

HARRIS, J.W. Effect of brood type on varroasensitive hygiene by worker honey bees (Hymenoptera: Apidae). Ann. Entomol. Soc. Am., v.101, p.1137-1144, 2008.

IBRAHIM, A.; SPIVAK, M. The relationship between hygienic behavior and suppression of mite reproduction as honey bee (Apis mellifera) mechanisms of resistance to Varroa destructor. Apidologie, v.37, p.1-40, 2006.

JUNKES, L.; GUERRA JÚNIOR, J.C.V.; MORETTO, G. Varroa destructor mite mortality rate according to the amount of worker broods in Africanized honey bee (Apis mellifera L.) colonies. Acta Sci. Biol. Sci., v.29, p.305-308, 2007.

LODESANI, M.; COSTA, C.; SERRA, G.; COLOMBO, R.; SABATINI, A.G. Acaricide residues in beeswax after conversion to organic beekeeping methods. Apidologie, v.39, p.324333, 2008.

MAGGI, M.; DAMIANI, N.; RUFFINENG, S. et al. Brood cell size of Apis mellifera modifies the reproductive behavior of Varroa destructor. Exp. Appl. Acarol., v.50, p.269-279, 2010.

MESSAGE, D; GONÇALVES, L. Effect of the size of worker brood cells of Africanized honey bees on infestation and reproduction of the ectoparasite Varroa jacobsoni Oud. Apidologie, v.26, p.381-386, 1995.

MORETTO, G. Defense of Africanized bee workers against the mite Varroa jacobsoni in southern Brazil. Am. Bee J., v.137, p.746-747, 1997.

MORETTO, G.; GONÇALVES, L.S.; DE JONG, D.; BICHUETTE, M.Z. The effects of climate and bee race on Varroa jacobsoni Oud infestations in Brazil. Apidologie, v.22, p.197203, 1991.

NEWTON, D.C.; OSTASIEWSKI Jr., N.J. A simplified bioassay for behavioral resistance to American foulbrood in honey bees (Apis mellifera L.). Am. Bee J., v.126, p.278-281, 1986. 
PENG, Y.S.; FANG, Y.; XU, S.; GE, L. The resistance mechanism of the Asian honey bee, Apis cerana Fabr., to an ectoparasitic mite Varroa jacobsoni Oudemans. J. Invertebr. Pathol., v.49, p.54-60, 1987.

PEROSA, J.M.Y.; ARAUCO, E.M.R.; SANTOS, M.L.A.; ALBARRACÍN, V.N. Parâmetros de competitividade do mel brasileiro. Inf. Econ., v.34, p.41-48, 2004.

PINTO, F.A.; PUKER, A.; BARRETO, L.M.R.C.; MESSAGE, D. Varroa destructor in Juquitiba, Vale do Ribeira, southeastern Brazil: seasonal effects on the infestation rate of ectoparasitic mites on honeybees. Sociobiology, v.57, p.511-518, 2011a.

PINTO, F.A.; SOUZA, G.K.; SANCHES, M.A.; SERRÃO, J.E. Parasitic effects of Varroa destructor (Acari: Varroidae) on hypopharyngeal glands of Africanized Apis mellifera (Hymenoptera: Apidae). Sociobiology, v.59, p.769-778, $2011 b$.
ROSENKRANZ, P.; AUMEIER, P.; ZIEGELMANN, B. Biology and control of Varroa destructor. J. Invertebr. Pathol., v.103, p.96-119, 2010.

SPIVAK, M. Honey bee hygienic behavior and defense against Varroa jacobsoni. Apidologie, v.27, p.245-260, 1996.

STRAPAZZON, R.; CARNEIRO, F.E.; GUERRA-JÚNIOR, J.C.V.; MORETTO, G. Genetic characterization of the mite Varroa destructor (Acari: Varroidae) collected from honey bees Apis mellifera (Hymenoptera, Apidae) in the state of Santa Catarina, Brazil. Gen. Mol. Res., v.8, p. 990-997, 2009. 